\title{
Differences between Androgen-dependent Cytosol Proteins in the Ventral and Dorsolateral Lobes of Rat Prostate*
}

\author{
By \\ Yuhsi Matuo**, Nozomu Nishi**, Yukio Tanaka** \\ Yasuyoshi Muguruma** and Fumio Wada**
}

\begin{abstract}
Summary
Androgen-dependent responses of the cytosol proteins from the ventral and dorsolateral lobes of the rat prostate were analyzed by SDS-electrophoresis. By castration, the relative content of the most abundant species, $16 \mathrm{~K}$ (protein species having a molecular weight of about 16,000) for the ventral lobe and $67 \mathrm{~K}$ for the dorsolateral lobe, was decreased in the ventral lobe, but increased in the dorsolateral lobe. Of the ventral lobe-specific proteins $(13 \mathrm{~K}, 14 \mathrm{~K}, 16 \mathrm{~K}$, and $20 \mathrm{~K}), 13 \mathrm{~K}$, $14 \mathrm{~K}$ and $20 \mathrm{~K}$ were decreased by castration and restored to control levels by replacement of androgen. Of the dorsolateral lobe-specific proteins, however, the relative content of $30 \mathrm{~K}$ was increased by castration and decreased by replacement of androgen; moreover, that of $120 \mathrm{~K}$ was hardly influenced. These changes by castration were faster, and those by replacement of androgen slower, in the ventral lobe than in the dorsolateral lobe, in accord with the changes in the tissue weights.
\end{abstract}

Key words : rat prostate, prostate protein, androgen, castration.

\section{Introduction}

We reported that subcellular proteins in the ventral and dorsolateral lobes of the rat prostate show characteristic profiles in SDS-polyacrylamide slab gel electrophoresis ${ }^{1)}$, and that a new species of non-histone chromosomal protein of 20,000-daltons, abundantly localized in the dorsolateral lobe, is reversibly changed in response to castration and replacement of androgen ${ }^{2,3)}$. Although the dorsolateral lobe, in addition to the ventral lobe, is known to be dependent on androgen for differentiation and maintenance of structural and functional properties, little is known about the difference in androgen-dependent changes of the cytosol proteins between the two lobes. Hence, the present work was undertaken to clarify first, the protein species that are changed by castration and replacement of androgen in the cytosol fractions of the rat prostate, and second, the difference in androgen-dependent changes between the two lobes, using SDSpolyacrylamide slab gel electrophoresis.

\section{Materials and methods}

Animals and preparation of cytosol fraction

Male adult rats of Sprague-Dawley strain (1415 weeks, $450-500 \mathrm{~g}$ ) were treated as described previously ${ }^{1,2)}$ : C-2, C-5 and $\mathrm{C}-8$, rats killed at 2 nd, 5 th and 8 th day, respectively, after castration; C8/T-3 and C-8/T-11, rats injected with testosterone propionate ( $2 \mathrm{mg}$ in $0.2 \mathrm{ml}$ of sesame oil) from 8 th day after castration for 3 and 11 days, respectively;

*ラットの腹部拉よび背側部前立腺に関する比較研究：SDS-電気泳動法を用いた可溶性蛋白質の分析とその男性ホ ルモン依存性変化の差違.

** 松尾雄志, 西 望, 田中幸夫, 六車謙喜, 和田文雄, 香川医科大学内分泌学講座.

（受付 1983年3月25日，受理１983年5月19日） 
$\mathrm{T}-10$, rats injected with testosterone propionate (2 $\mathrm{mg}$ in $0.2 \mathrm{ml}$ of sesame oil) for 10 days. Cytosol fractions were prepared using the same methods as those described previously in the presence of 1 mM PMSF ${ }^{1,2)}$.

SDS-polyacrylamide slab gel electrophoresis

Slab gel electrophoresis in the presence of SDS was carried out by the methods described previously ${ }^{1,2)}$, using a slab gel with a size of $176 \mathrm{~mm}$ (height) $\times 150 \mathrm{~mm}$ (width) $\times 2 \mathrm{~mm}$ (thickness) and concentrations of $13 \%$ acrylamide and $0.37 \%$ BIS. The cytosol proteins $(100 \mu \mathrm{g})$ were analyzed. The molecular weights of protein species measured by SDS-electrophoresis are shown as apparent molecular weights.

Staining and densitometry ${ }^{1)}$

The gel was subjected to protein staining with $0.25 \%$ Coomassie Brilliant Blue R-250 containing $35 \%$ ethanol and $9.2 \%$ acetic acid under shaking, followed by destaining with a mixture of $25.5 \%$ ethanol and $8.2 \%$ acetic acid. The gel was further destained with $5 \%$ methanol containing $7.5 \%$ acetic acid. The stained gel was dried in a slab gel dryer (Koike Precision Instruments, Kawasaki). The resulting gel film was measured for absorbance at $.560 \mathrm{~nm}$ by a densitometer (model CS-910, Shimadzu Seisakusho, Kyoto).

Designation of protein species and measurements of their contents

Protein species separated in the gel are expressed as $\mathrm{K}$ (apparent molecular weight of the species $\left.\times 10^{-3}\right)$. The content of a species separated in the gel was measured from the densitograms by planimeter. "Relative content" of a species separated in the gel was calculated from the equation : (density of a species)/(density of all the species) $\times 100(\%)$. "Total content" was calculated from the equation : relative content $\times$ content of protein $(\mu \mathrm{g}$ $/ g$ tissue $) \times$ tissue weight $(\mathrm{g}) / 100 \mathrm{~g}$ body weight. Protein species of relative content higher than $3 \%$ in the control rats were designated major species. The most abundant species were defined as a species of the highest relative content in the control rats.
Determination of protein and DNA contents

The contents of protein and DNA were determined by the methods of Lowry et al. ${ }^{5)}$ and Schnei$\operatorname{der}^{6}$, respectively.

\section{Results}

Androgen-dependent changes in tissue weight and protein content in the ventral and dorsolateral lobes

The body weight of the rats was hardly influenced by castration and androgen injection. By castration, tissue weight (Table 1) and protein in the homogenate (Table 2) were decreased in the two lobes. These decreases by castration were restored to control levels by androgen injections to $\mathrm{C}-8$ rats in both lobes. The extents of the decreases were higher, and those of restoration lower, in the ventral lobe than in the dorsolateral lobe. The extents of the increases in the tissue weight due to injection of an excess amount of androgen ( $\mathrm{T}-10$ in Table 1) were higher in the dorsolateral lobe than in the ventral lobe.

Androgen-dependent changes of cytosol proteins in the ventral and dorsolateral lobes

The protein yields of the cytosol fractions from the homogenates were hardly influenced by castration and androgen injection in the two lobes (Table 2). The cytosol fractions containing $100 \mu \mathrm{g}$ protein were analyzed by SDS-electrophoresis. On the resulting electrophoretic profiles, the changes in the contents of protein species in the two lobes by castration and androgen injection were examined.

1) Ventral lobe : Of the about 37 bands of proteins from the cytosol protein in the ventral lobe, which were separated in the densitogram, all the major species except $67 \mathrm{~K}$ were decreased in their relative contents in $\mathrm{C}-8$ rats (Fig. 1 and Table 3); the extents of the decreases in C- 8 rats were in the order : $14 \mathrm{~K}>57 \mathrm{~K}>12 \mathrm{~K}>20 \mathrm{~K}>16 \mathrm{~K}>13 \mathrm{~K}$. Of all the species, $14 \mathrm{~K}$ was most susceptible to decrease through whole stages of castration. The relative content of $67 \mathrm{~K}$ was increased by castration. By androgen injections into $\mathrm{C}-8$ rats for 3 and 11 days, the relative contents of all the major species except $16 \mathrm{~K}$ were restored to control levels. The most 
Table 1. Effects of castration and testosterone injections on body weight and tissue weight of the ventral and dorsolateral lobes.

\begin{tabular}{l|c|c|c}
\hline \hline \multirow{2}{*}{ Rat groupa) } & Body weight (g) & $\begin{array}{r}\text { Tissue weight }(\mathrm{mg} / 100 \mathrm{~g} \text { body weight) } \\
\text { Mean } \pm \text { S.D. }\end{array}$ \\
\cline { 2 - 4 } & Mean \pm S.D. & Ventralb) & Dorsolateralb) \\
\hline Control (6) & $462 \pm 11$ & $132 \pm 21(100)$ & $67 \pm 14(100)$ \\
Sham oper. (4) & $501 \pm 22$ & $125 \pm 15(95)$ & $72 \pm 6(107)$ \\
C-2 (7) & $450 \pm 16$ & $98 \pm 21(74)$ & $57 \pm 9(85)$ \\
C-5 (14) & $438 \pm 11$ & $41 \pm 6(31)$ & $40 \pm 7(60)$ \\
C-8 (15) & $458 \pm 23$ & $24 \pm 5(18)$ & $29 \pm 5(43)$ \\
C-8/T-3 (15) & $508 \pm 37$ & $47 \pm 10(36)$ & $53 \pm 7(79)$ \\
C-8/T-11 (18) & $533 \pm 41$ & $114 \pm 17(86)$ & $99 \pm 13(148)$ \\
T-10 (7) & $452 \pm 13$ & $199 \pm 22(151)$ & $117 \pm 13(175)$ \\
\hline
\end{tabular}

a) The number of rats used in each experiment is shown in parentheses. The number of experiments was 11 and 3 for control and others, respectively. The results for the normal rats ( 15 weeks) were statistically the same as for those of control rats. Control : rats received a daily subcutaneous injection of sesame oil $(0.4 \mathrm{ml})$ for 10 days. Sham oper. : rats killed at 8 th day after sham operation. C-2, C-5 and C-8: rats killed at 2 nd, 5 th and 8 th day, respectively, after castration. C-8/T-3 and C-8/T-11: rats received a daily subcutaneous injection of testosterone propionate $(2 \mathrm{mg}$ in $0.2 \mathrm{ml}$ of sesame oil) for 3 and 11 days, respectively, from 8 th day after castration.

b) Relative mean values of tissue weights are shown in parentheses. The mean value of control was taken as $100 \%$.

Table 2. Effects of castration and testosterone injections on protein contents in cytosol fractions in the ventral and dorsolateral lobes.

\begin{tabular}{l|c|c|c|c}
\hline \multirow{2}{*}{ Rat groupa) } & \multicolumn{4}{|c}{ Protein content (mg/g tissue) } \\
\cline { 2 - 5 } & \multicolumn{2}{|c|}{ Homogenate $^{\text {b) }}$} & \multicolumn{2}{|c}{ Cytosol fractionc } \\
\cline { 2 - 5 } & Ventral & Doasolateral & Ventral & Dorsolateral \\
\hline Control & $112.1(100)$ & $86.6(100)$ & $68.3(61)$ & $43.3(50)$ \\
Sham oper. & $96.2(86)$ & $94.1(109)$ & $59.6(62)$ & $45.2(48)$ \\
C-2 & $92.3(82)$ & $77.6(90)$ & $60.7(66)$ & $33.7(43)$ \\
C-5 & $77.9(69)$ & $70.7(82)$ & $49.4(63)$ & $33.2(47)$ \\
C-8 & $72.3(64)$ & $67.9(78)$ & $41.9(58)$ & $30.3(45)$ \\
C-8/T-3 & $81.0(72)$ & $71.9(83)$ & $46.5(57)$ & $29.1(40)$ \\
C-8/T-11 & $89.5(80)$ & $81.5(94)$ & $51.4(57)$ & $38.9(48)$ \\
T-10 & $111.6(100)$ & $95.0(110)$ & $63.8(57)$ & $43.6(46)$ \\
\hline
\end{tabular}

a) See the footnotes to Table 1 .

b) Relative values are shown in parentheses. The values of control were taken as $100 \%$.

c) Yields from the homogenates are shown in parentheses.

abundant species (16 K) was restored to about $70 \%$ of control level in $\mathrm{C}-8 / \mathrm{T}-11$ rats. The total content of $67 \mathrm{~K}$ was transiently increased in $\mathrm{C}-2$ rats, but decreased in C-5 and C-8 rats, and those of other major protein species were decreased by castration. Of the decreased protein species, the total content 


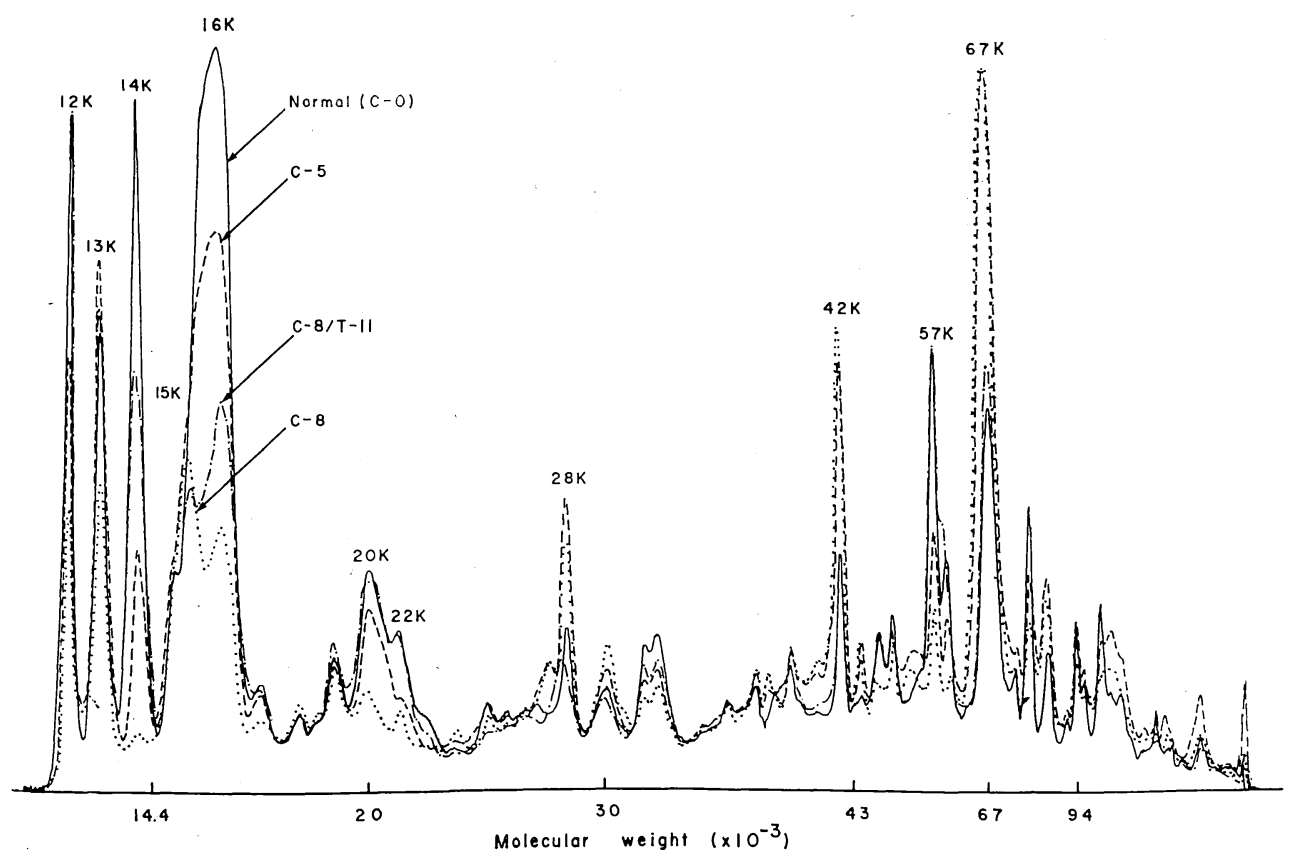

Fig. 1. Effects of castration and replacement of androgen on the cytosol proteins from the ventral lobe. Each sample (100 $\mu$ g protein) prepared from rats shown in Table 1 was subjected to SDS-electrophoresis. With the sample from the same group of rats, the reproducibility of electrophoretic profile was reasonably good. The profile for C-0 (control) rats (-) was essentially the same as for that of normal rats and rats of sham operation. C-5 (-- ), rats killed at 5 th day after castration; C-8 ( $\cdots \cdots)$, rats killed at 8 th day after castration; C-8/T-11 (-.- -), rats injected with testosterone propionate for 11 days from 8 th day after castration. The data for C-2, C-8/T-3 and T-10 are not shown.

Table 3. Effects of castration and testosterone injections on contents of major protein species in electrophoretic profiles for cytosol fractions from the ventral lobe.

\begin{tabular}{l|c|c|c|c|c|c|c}
\hline \hline \multirow{2}{*}{ Rat group } & \multicolumn{7}{|c}{ Relative content of major species (\%)b } \\
& $12 \mathrm{~K}$ & $13 \mathrm{~K}$ & $14 \mathrm{~K}$ & $16 \mathrm{~K}$ & $20 \mathrm{~K}$ & $57 \mathrm{~K}$ & $67 \mathrm{~K}$ \\
\hline Control & $9(100)$ & $6(100)$ & $10(100)$ & $26(100)$ & $7(100)$ & $5(100)$ & $6(100)$ \\
C-2 & $6(42)$ & $6(63)$ & $5(30)$ & $23(57)$ & $5(51)$ & $2(31)$ & $14(148)$ \\
C-5 & $6(14)$ & $5(20)$ & $4(9)$ & $23(20)$ & $5(17)$ & $2(10)$ & $14(51)$ \\
C-8 & $4(5)$ & $4(7)$ & $2(2)$ & $14(6)$ & $4(6)$ & $2(3)$ & $14(25)$ \\
C-8/T-3 & $9(24)$ & $6(29)$ & $5(11)$ & $15(14)$ & $4(15)$ & $3(14)$ & $12(49)$ \\
C-8/T-11 & $9(68)$ & $7(73)$ & $14(90)$ & $18(46)$ & $8(77)$ & $5(69)$ & $7(77)$ \\
T-10 & $10(152)$ & $7(158)$ & $10(146)$ & $27(148)$ & $8(155)$ & $5(141)$ & $6(142)$ \\
\hline
\end{tabular}

a) See the footnote to Table 1 .

b) The relative contents of $16 \mathrm{~K}$ and $20 \mathrm{~K}$ contains those of $15 \mathrm{~K}$ and $22 \mathrm{~K}$, respectively (see Fig. 1). The values in parentheses show relative "total contents". The values of control rats were taken as $100 \%$. 


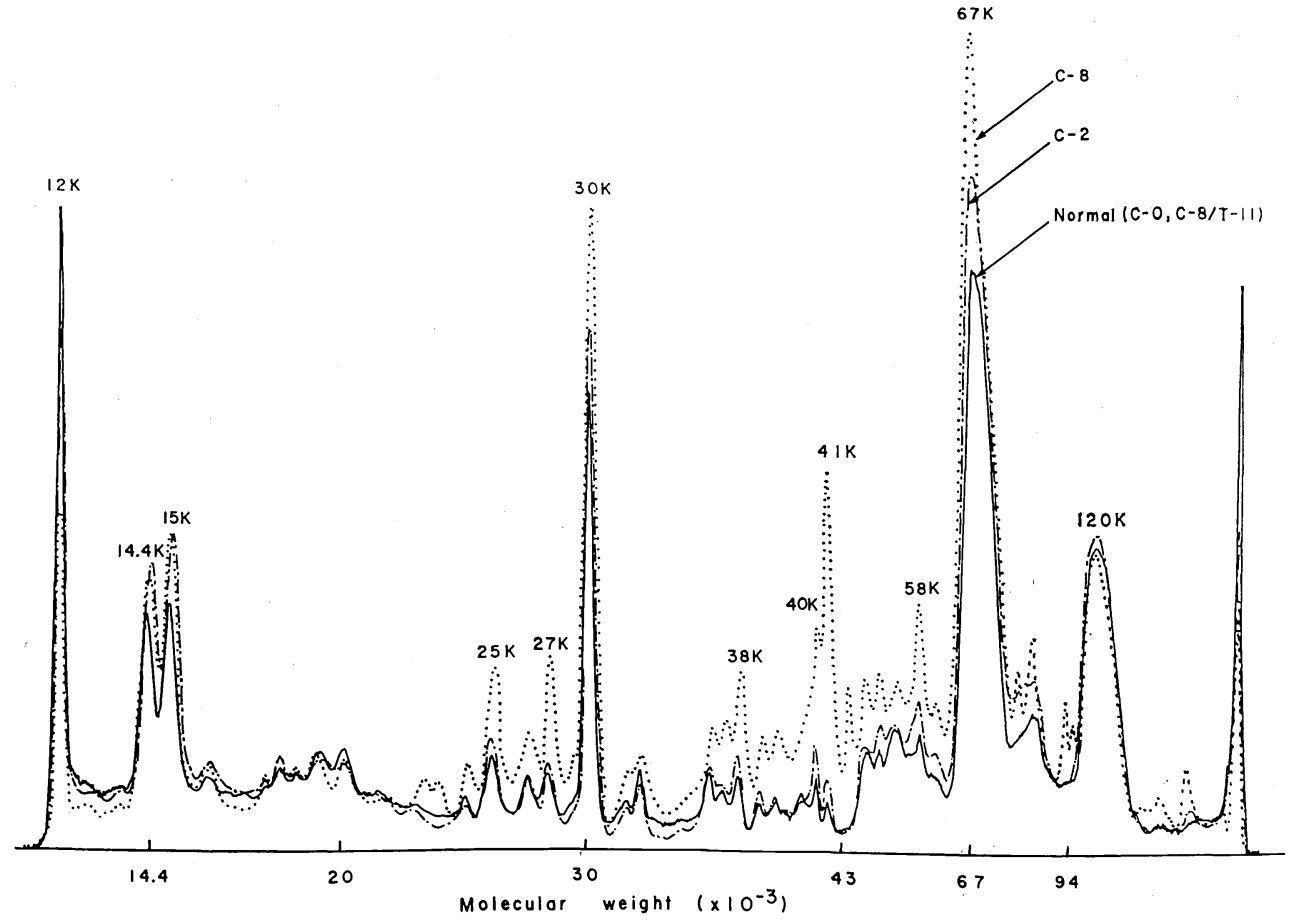

Fig. 2. Effects of castration and replacement of androgen on the cytosol proteins from the dorsolateral lobe. The profile for C-8/T-11 rats ( - ) was essentially the same as for that of control rats and rats of sham operation. C-2 (-. - ), rats killed at 2 nd day after castration; C-8 (…), rats killed at 8 th day after castration. Other experimental conditions were the same as for those described in the legend to Fig. 1.

Table 4. Effects of castration and testosterone injections on contents of major protein species in electrophoretic profiles for cytosol fraction from the dorsolateral lobe.

\begin{tabular}{l|c|c|c|c|c|c}
\hline \hline \multirow{3}{*}{ Rat group } & \multicolumn{6}{|c}{ Relative content of major species (\%)a } \\
\cline { 2 - 7 } & $12 \mathrm{~K}$ & $\begin{array}{c}(14.4 \mathrm{~K}+ \\
\left.15 \mathrm{~K})^{\mathrm{b}}\right)\end{array}$ & $30 \mathrm{~K}$ & $41 \mathrm{~K}^{\mathrm{c})}$ & $67 \mathrm{~K}$ & $120 \mathrm{~K}$ \\
\hline Control & $8(100)$ & $11(100)$ & $10(100)$ & $0.5(100)$ & $24(100)$ & $14(100)$ \\
C-2 & $7(62)$ & $14(86)$ & $11(74)$ & $0.8(99)$ & $28(78)$ & $16(73)$ \\
C-5 & $6(33)$ & $15(60)$ & $13(58)$ & $5(411)$ & $31(60)$ & $14(45)$ \\
C-8 & $6(21)$ & $15(41)$ & $13(39)$ & $5(273)$ & $32(41)$ & $14(30)$ \\
C-8/T-3 & $8(52)$ & $11(53)$ & $7(39)$ & $1(107)$ & $27(60)$ & $13(48)$ \\
C-8/T-11 & $8(130)$ & $11(133)$ & $8(100)$ & $0.5(134)$ & $23(128)$ & $13(120)$ \\
T-10 & $8(174)$ & $11(183)$ & $7(127)$ & $0.5(176)$ & $22(163)$ & $14(172)$ \\
\hline
\end{tabular}

a) See the footnote to Table 3.

b) Relative contents of $14.4 \mathrm{~K}$ plus $15 \mathrm{~K}$ (see Fig. 2).

c) To show the most susceptible species, the content of $41 \mathrm{~K}$ was indicated, although $41 \mathrm{~K}$ was not major species.

of $14 \mathrm{~K}$ was reduced to $2 \%$ of control level by castration. Species other than $16 \mathrm{~K}$ were restored to $70-90 \%$ of control levels in C-8/T-11 rats. The injection of an excess amount of androgen caused 1. 4-1.6 fold increase in the total contents, but little change in the relative contents, of all the major 
species ( $T-10$ in Table 3 )

2) Dorsolateral lobe: All the major species except $12 \mathrm{~K}$ and $120 \mathrm{~K}$ were increased in relative content by castration (Fig. 2 and Table 4); the extents of the increases in $\mathrm{C}-8$ rats were in the order : $67 \mathrm{~K}=(14.4 \mathrm{~K}+15 \mathrm{~K})>30 \mathrm{~K}$. By castration, the relative content of $12 \mathrm{~K}$ was decreased, but that of $120 \mathrm{~K}$ was hardly influenced. Of all the species, $41 \mathrm{~K}$ was most susceptible to increase in entire period after castration. By androgen injections into $\mathrm{C}-8$ rats for 3 and 11 days, the relative contents of $12 \mathrm{~K},(14.4 \mathrm{~K}+15 \mathrm{~K})$ and $67 \mathrm{~K}$ were restored to control levels, and the content of $30 \mathrm{~K}$ was decreased under control level. The total contents of all the major species were decreased by castration; the extents of the decrease were in the order : 12 $\mathrm{K}>120 \mathrm{~K}>30 \mathrm{~K}>67 \mathrm{~K}=(14.4 \mathrm{~K}+15 \mathrm{~K})$ in $\mathrm{C}-8$ rats. By androgen injections into $\mathrm{C}-8$ rats, all the major species were restored to control levels, and the total contents of $12 \mathrm{~K},(14.4 \mathrm{~K}+15 \mathrm{~K}), 67 \mathrm{~K}$ and $120 \mathrm{~K}$ were increased in C-8/T-11 rats. The injection of an excess amount of androgen caused 1.61.8 fold increase in the total contents, but no increase in the relative contents, of all the major species except $30 \mathrm{~K}$ (T-10 in Table 4).

Comparison between androgen-dependent cytosol protein in the ventral lobe and in dorsolateral lobe

When the changes of the contents by castration and replacement of androgen were compared with respect to the most abundant species and lobe-specific species in the cytosol fraction between the lobes, there were distinct differences: 1) The relative content of $16 \mathrm{~K}$, abundantly and specifically localized in the ventral lobe, was decreased by castration. Its restoration was not complete in C-8/ $\mathrm{T}-11$ rats, whereas the relative content of $67 \mathrm{~K}$, abundant in the dorsolateral lobe, was increased by castration and its restoration was complete in C-8 /T-11.2) The relative and total contents of the ventral lobe-specific proteins, $13 \mathrm{~K}, 14 \mathrm{~K}$ and $20 \mathrm{~K}$ were decreased by castration and restored to control levels by replacement of androgen. Of the dorsolateral lobe-specific proteins, however, the relative content of $30 \mathrm{~K}$ was increased by castration and returned to control levels by replacement of androgen, whereas that of $120 \mathrm{~K}$ was hardly influenced. 3) The relative and total contents of all the major species in the ventral lobe were more susceptible to castration than those in the dorsolateral lobe, moreover, the restoration to control levels by replacement of androgen was faster in the dorsolateral lobe than in the ventral lobe.

\section{Discussion}

It was already reported that, in the cytosol fraction of the ventral lobe, there are several predominant proteins whose synthesis is dependent on androgen, and that their molecular weights are measured to be in the range of $6,000 \sim 22,000^{7} 12$ ). In the present study, the presence of these androgen-dependent proteins were reproduced as $12 \mathrm{~K}$, $13 \mathrm{~K}, 14 \mathrm{~K}$ and $16 \mathrm{~K}$ in the cytosol fraction of the ventral lobe. These proteins with the exception of $12 \mathrm{~K}$ were found to be undetectable in the cytosol fraction of the dorsolateral lobe, indicating that they were androgen-dependent proteins specifically localized in the cytosol fraction of the ventral lobe. We found that $30 \mathrm{~K}$ and $120 \mathrm{~K}$ were specifically localized in the dorsolateral lobe, and that the relative content of $30 \mathrm{~K}$ was increased, whereas that of $120 \mathrm{~K}$ was hardly influenced, by castration. The reason why total density of protein species stained with Coomassie Brilliant Blue R-250 was slightly higher in the dorsolateral lobe of C-8 rats than control rats (Fig. 2) is not clear. It is reasonable, however, to discuss androgen-dependent changes in the major protein species.

In accord with the changes in tissue weight and protein content in the homogenate, the contents of major protein species in the cytosol fractions were more rapidly decreased by castration in the ventral lobe than in the dorsolateral lobe, but more rapidly restored to control levels by replacement of androgen in the dorsolateral lobe than in the ventral lobe. Excess injection of androgen indicated that almost all of the major protein species were more inducible in the dorsolateral lobe than in the ventral lobe. The injection of an excess amount of 
androgen caused an increase in the total contents, but not in the relative contents, of all the major species of the two lobes. These suggest the differences in the hormonal regulation between the total contents and the relative contents. These findings were not caused by proteolytic digestion during the preparation of the cytosol fractions, because the changes in electrophoretic profiles for castrated rats and rats injected with androgen were negligible in the presence of PMSF ; the electrophoretic patterns were hardly influenced by elimination of PMSF and by incubation at $37^{\circ} \mathrm{C}$ in the presence of $\mathrm{PMSF}^{1)}$.

\section{Acknowledgment}

We are very thankful to Prof. T. Horio (Division of Enzymology, Institute for Protein Research, Osaka University) for his fruitful suggestions and constant help.

\section{References}

1) Matuo, Y, et al. : Electrophoresis, $3: 293,1982$.

2) Matuo, Y. et al. : Biochem. Biophys. Res. Commun., $107:$ 209, 1982.

3) Matuo, Y. et al. : Biochem. Biophys. Res. Commun., 109 : 334, 1982.

4) Hirano, N. et al. : Gann, 72 : 346, 1981.

5) Lowry, O.H. et al. : J. Biol. Chem., $193: 265$. 1951.

6) Schneider, E.C. : Methods Enzymol. 3, Academic Press, New York, 1957, 680.

7) Parker, M. G., et al. : Biochem. J., $170: 115$, 1978.

8) Heyns, W. et al. : Eur. J. Biochem., 89 : 181, 1978.

9) Carter, D. B. et al. : Arch. Androl., 6: 133,
1981.

10) Lea, O.A., and French, F.S. : J. Biol. Chem., $254: 6196,1979$.

11) Forsgren, B. et al. : Proc. Nat. Acad. Sci., 76 : 3149, 1979.

12) Liao, S. et al. : Prostate Cancer and Hormone Receptors, Alan Liss, New York, 1979, 3.

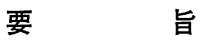

ラットの腹部前立腺 (VP) と背側部前立腺 (DLP) から可溶性画分を調製し，含まれる蛋白質をSDS-電 気泳動法によって分離した．分離された種々の蛋白質 が去勢および去勢後のテストステロン投与（以後，十 Tと略す）によって変化する様子を解析 し，VP と DLP の間における差を調べた。実験にはオスの SD 系ラット（14〜15週齢）を用いた. 蛋白質種の含量は 可溶性画分中の蛋白質 $100 \mu \mathrm{g}$ を分析し，得られたデ ンシトグラム上での相対面積值から求めた.

1. 含量が最大の蛋白質の変化：VP に括ける最大 含量の蛋白質, $16 \mathrm{~K}$ (分子量約1.6万のポリペプチド), の含量は去勢によって減少したが，DLP に拈ける最 大含量の蛋白質, $67 \mathrm{~K}$, は増加した. 2 . 特異的な蛋 白質の変化：VP に特異的な $13 \mathrm{~K}, 14 \mathrm{~K}$ 执よび $20 \mathrm{~K} の$ 含量は去勢によって減少し，十Tによって正常に厌っ た.しかし，DLP に特異的な蛋白質の中で， $30 \mathrm{~K}$ 含 量は去勢によって増加し，十Tによって正常以下に減 少した。また，120K含量は去勢稀よび十 Tによって ほとんど影響を受けなかった，以上の様に，VPと DLP の間には著しい差が認められ，これらの蛋白質 の去勢による変化はVPに拈いて早く現われ，一方， 十Tによる変化は DLPに打いて早く現われ，組織重 量の変化とよく一致した. 